\title{
Article \\ Assessment of Saudi Mother's Knowledge and Attitudes towards Childhood Diarrhea and Its Management
}

\author{
Sultan Alghadeer, Wajid Syed*(D), Abdulaziz Alhossan, Ziyad Alrabiah, Salmeen D. Babelghaith, \\ Mohamed N. Al Arifi and Abdulrahman Alwhaibi
}

check for

updates

Citation: Alghadeer, S.; Syed, W.;

Alhossan, A.; Alrabiah, Z.;

Babelghaith, S.D.; Al Arifi, M.N.;

Alwhaibi, A. Assessment of Saudi

Mother's Knowledge and Attitudes towards Childhood Diarrhea and Its Management. Int. J. Environ. Res. Public Health 2021, 18, 3982.

https://doi.org/10.3390/ijerph18083982

Academic Editor: Paul B. Tchounwou

Received: 18 January 2021

Accepted: 24 March 2021

Published: 9 April 2021

Publisher's Note: MDPI stays neutral with regard to jurisdictional claims in published maps and institutional affiliations.

Copyright: (C) 2021 by the authors. Licensee MDPI, Basel, Switzerland This article is an open access article distributed under the terms and conditions of the Creative Commons Attribution (CC BY) license (https:// creativecommons.org/licenses/by/ $4.0 /)$
Department of Clinical Pharmacy, College of Pharmacy, King Saud University, Riyadh 11451, Saudi Arabia; salghadeer@ksu.edu.sa (S.A.); alhossan@ksu.edu.sa (A.A.); Zalrabiah@ksu.edu.sa (Z.A.); sbabelghaith@ksu.edu.sa (S.D.B.); malarifi@ksu.edu.sa (M.N.A.A.); aalwhaibi@KSU.EDU.SA (A.A.)

* Correspondence: wali@ksu.edu.sa; Tel.: +966-503754169

Abstract: This study evaluates the knowledge, attitude of Saudi mothers towards diarrhea in their children and its management at home. Online cross-sectional validated online surveys, targeting Saudi mothers who are living in Saudi Arabia, are used to collect data from the beginning of March to the end of April 2019. Our results show that a total of 1140 mothers (52.1\% of them were housewives) participated in the study. Approximately $40.3 \%$ of participating mothers believed that childhood diarrhea is a major problem in the Saudi community; however, almost $23 \%$ of the participants were unable to identify any critical sign of severe diarrhea, and around $66 \%$ falsely stated that diarrhea is caused by teething. Although $62 \%$ of our participating mothers knew about oral rehydration therapy (ORS), only $23.5 \%$ of them used it for their children. Adequate knowledge about the critical signs, causes, transmission, prevention, and management of childhood diarrhea should be applied in simple language to communicate the health-related information clearly.

Keywords: diarrhea; Saudi Arabia; knowledge; attitude; children; mother

\section{Introduction}

Diarrhea is a common illness that is considered a major threat to children, and it may lead to death in developing countries, particularly amongst children aged up to five years [1-3]. Twelve million children are estimated to die in developing countries before the age of five years. Around $70 \%$ of those children die because of five medical issues; one of them is diarrhea [1,4]. Despite that age, climate changes, and the use of rotavirus vaccine can contribute to variations in pathogen-causative diarrhea; rotavirus was the most common causative pathogen, especially in unvaccinated children against rotavirus [5]. In Saudi Arabia, rotavirus was noticed in $41.3 \%$ to $65.5 \%$ of cases causing the child's diarrhea [6,7]. In addition to microbial-induced diarrhea, diarrhea can result from intolerance of certain kinds of food, particularly lactose-containing milk [8].

Regardless of diarrhea-induced causes, dirty weaning food, improper nourishing practice, absence of clean water, poor hand washing, constrained sterile transfer of waste, poor lodging conditions, and absence of access to satisfactory and moderate social insurance are aggravating factors of diarrhea in children under five years old [9]. A study in Saudi Arabia reported that environmental risk factors associated with diarrhea in children included sewage leakage near the home, eating out after school hours, and utilizing reusable cloths or sponges to dry dishes [10].

Enhancing mothers' proper knowledge and demonstrating appropriate practice is a key to prevent or halt the progression of diarrhea. However, mothers' harmful practices, such as nourishment limitation, breastfeeding avoidance, and utilization of inappropriate conventional therapy or wrong prescription, have been reported [11]. In addition, the mothers' knowledge on the signs of dehydration secondary to diarrhea is poor [2,12]. In most cases, diarrhea can be treated at home by oral rehydration therapy (ORT) that has 
significantly decreased the mortality related to diarrhea disease [13]. Although this method of treatment is cheap, adequate, reasonable, and safe, few mothers listed that the aim of using (ORS) during diarrhea is to treat dehydration of diarrhea [2,13]. To demonstrate the best home care of children with diarrhea in our community by investigating certain knowledge, attitude, and particular practice toward diarrhea in children, and its management is essential. Therefore, this study evaluates the knowledge and attitudes of mothers towards diarrhea in children and its management at home in Saudi Arabia.

\section{Methods and Materials}

\subsection{Design and Settings}

Online cross-sectional survey-based study targeting mothers who are living in Saudi Arabia were carried out to measure knowledge, attitude, and practice of mothers towards diarrhea and its management in their children at home. The data collection was carried out from the beginning of March to the end of April 2019. Saudi women bearing at least one child below the age of five years were included in the study.

\subsection{Design of the Questionnaires}

The questionnaires for this study were prepared after an extensive literature review from similar studies published in this regard [14,15]. The questionnaires for this study are grouped into four parts. The first part was to collect demographic data (such as the mother's age, the mother's education level, the mother's job, the child's age, etc.). The second part is the knowledge domain questions with the multiple-choice options discussing subjects like signs and symptoms of diarrhea, diarrhea causes, preventive measures, and critical signs of diarrhea, as well as critical signs of dehydration. The third part focused on the manner of management practice of diarrhea at home. The fourth part was the attitude domain questions that were composed of 11 questions assessed by a 5-point Likert Scale (strongly agree, agree, neutral, disagree, and strongly disagree). A panel of three members (two professors and a researcher) from the College of Pharmacy, King Saud University, who were experts in preparing the study tool were reviewed the questionnaire. The survey was translated into Arabic by an independent translator, and reviewed again for the appropriateness of language before testing its validity. The questionnaire was then validated through randomly selected 10 respondents in a pilot study carried out at the College of Pharmacy, King Saud University. The respondents recruited in the pilot study were mothers and did not include them in the final results or had no contact with the subjects of the study. The reliability test was determined using Cronbach's alpha of the questionnaire for knowledge (0.73), attitudes, and (0.71) suggested that questionnaires can be used to carry out the study.

\subsection{Participants Recruitment Procedure}

The validated Arabic questionnaires were used for data collection. Social media platforms were chosen as the potential medium for data collection using the snowball technique. For the purpose of data collection, a team of three female students were appointed from the female campus of the College of Pharmacy, King Saud University, and given clarity about inclusion and exclusion criteria and the procedure of data collection through social media platforms. The data collators were strictly investigated by two senior academicians of the pharmacy college. The data collectors had to ensure that the questionnaires reached all the regions of Saudi Arabia. The questionnaires started with a pre-condition that stated that "Saudi females with at least one child are only eligible to fill in the questionnaire; females without children are not allowed to complete the questionnaires. During the data collection period, we received a total of 1140 responses. According to the timeline of the data collection period, we stopped receiving the responses once the timeline end. 


\subsection{Sample Size Estimation}

According to previous reports, the prevalence of diarrhea among pediatrics was $56.3 \%$ [16]. The sample size for the given study was calculated by using the following Equation (1):

$$
n=\mathrm{z}^{2} \times \mathrm{p} \times \mathrm{q} / \mathrm{d}^{2}
$$

where $n$ is the minimum sample size, $z$ is the constant (1.96), $\mathrm{p}$ is the prevalence of diarrhea (among pediatrics, it was $0.563 \%$ ), $\mathrm{q}$ is $(1-\mathrm{p}$ ), $\mathrm{Z}$ is the standard normal deviation of 1.96 , corresponding to the $95 \%$ confidence interval, and $\mathrm{d}$ is the desired degree of accuracy.

$$
\begin{gathered}
N=(1.96)^{2} \times 0.563 \times(1-0.563) /(0.05)^{2} \\
n=378
\end{gathered}
$$

\subsection{Data Analysis}

Statistical Package for Social Sciences version IBM SPSS Statistics 26 (IBM Inc., Chicago, IL, USA) software was applied to analyze the data. Descriptive statistics, including percentages and frequencies, were used to present the results.

\section{Results}

\subsection{Sample Characteristics}

A total of 1140 respondents filled the questionnaire. About $24 \%$ of respondents were aged from 36 to 40 years, and only $5.4 \%$ of respondents received no formal education. More than half of mothers were housewives $(52.1 \%)$. Slightly more than one-third of children were aged above two years. The demographic of mothers and their children are

\begin{tabular}{|c|c|c|}
\hline Variables & Number & Percentage \\
\hline \multicolumn{3}{|l|}{ Age of the Mothers (years) * } \\
\hline $18-20$ & 130 & 11.4 \\
\hline $21-25$ & 130 & 11.4 \\
\hline $26-30$ & 166 & 14.6 \\
\hline $31-35$ & 192 & 16.8 \\
\hline $36-40$ & 271 & 23.8 \\
\hline more than 41 years & 248 & 21.8 \\
\hline \multicolumn{3}{|l|}{ Education level } \\
\hline Illiterate & 62 & 5.4 \\
\hline Primary school/secondary school & 160 & 14 \\
\hline High school & 244 & 21.4 \\
\hline University & 479 & 42 \\
\hline Postgraduate & 195 & 17.1 \\
\hline \multicolumn{3}{|l|}{ Job } \\
\hline Employer & 427 & 37.5 \\
\hline Health staff & 68 & 6 \\
\hline Housewife & 594 & 52.1 \\
\hline Students & 39 & 3.4 \\
\hline Other's & 12 & 1 \\
\hline \multicolumn{3}{|l|}{ Insurance } \\
\hline None & 329 & 28.9 \\
\hline Governmental & 482 & 42.3 \\
\hline Private & 329 & 28.9 \\
\hline \multicolumn{3}{|l|}{ Age of the child (years) } \\
\hline Less than on year & 217 & 19 \\
\hline $1-2$ years & 226 & 19.8 \\
\hline Above 2 years & 697 & 61.1 \\
\hline \multicolumn{3}{|l|}{ Gender of a child } \\
\hline Male & 456 & 40 \\
\hline Female & 675 & 59.2 \\
\hline
\end{tabular}
summarized in Table 1.

Table 1. Demographic data of mothers and their children.

* Missing Data. 


\subsection{Mothers' Knowledge about Childhood Diarrhea}

In this study, the mother rated the critical signs of childhood diarrhea as follows: Blood in the stool (49\%), followed by thirst and dry mouth (32.1\%), and loss of stretchiness of the skin $(24.3 \%)$. Nearly half $(n=569 ; 49.9 \%)$ of mothers believed that diarrhea is caused by eating dirty food, while $(n=516) 45.3 \%$ of them thought that eating expired food; also, ( $n=470) 41.2 \%$ of them believed that eating with dirty hand cause the transmission of diarrhea. Furthermore, a detailed description of mothers' knowledge about childhood diarrhea was given in Table 2.

Table 2. Mothers' knowledge about diarrhea and its management.

\begin{tabular}{|c|c|c|}
\hline Variables & $N$ & $\%$ \\
\hline \multicolumn{3}{|l|}{$\begin{array}{c}\text { Critical signs and symptoms of } \\
\text { diarrhea * }\end{array}$} \\
\hline Passage of $>3$ loose stools with blood in $24 \mathrm{~h}$ & 553 & 48.5 \\
\hline Thirst and dry mouth & 366 & 32.1 \\
\hline Tearless eyes & 132 & 11.6 \\
\hline Loss of stretchiness of the skin & 277 & 24.3 \\
\hline I do not know & 261 & 22.9 \\
\hline \multicolumn{3}{|l|}{$\begin{array}{c}\text { Cause/mode of transmission of } \\
\text { diarrhea * }\end{array}$} \\
\hline Drinking bad/dirty water & 361 & 31.7 \\
\hline Eating dirty food & 569 & 49.9 \\
\hline Eating with dirty hands & 470 & 41.2 \\
\hline Eating expired food & 516 & 45.3 \\
\hline Insects feeding on dirty tools & 231 & 20.3 \\
\hline Bottle of breastfeeding & 235 & 20.6 \\
\hline Unpasteurized milk & 226 & 19.8 \\
\hline \multicolumn{3}{|l|}{ Management of child's diarrhea } \\
\hline Visit the physician & 786 & 68.9 \\
\hline Visit the pharmacist & 233 & 20.4 \\
\hline Use ORS & 262 & 23 \\
\hline Give homemade fluids & 600 & 52.6 \\
\hline Feed the child with breastfeeding & 100 & 8.8 \\
\hline Stop feeding & 53 & 4.6 \\
\hline Nothing & 41 & 3.6 \\
\hline
\end{tabular}

${ }^{*}$ Multiple-answers question.

In this study, the most reported practice among mothers towards management of their child's diarrhea included seeing the physicians (68.9\%), giving homemade fluids (52.6\%), using ORS (23.0), and visiting pharmacists (20.4) (Table 2).

\subsection{Mothers' Knowledge about the Use of ORS}

In this study, about $62 \%$ of mothers know the ORS, but only $53.5 \%$ of them recognized that ORS could prevent the child from getting dehydrated. The resources of information for utilizing ORS in childhood diarrhea were gained mainly from medical prescription $(50.3 \%)$, followed by family $(15.7 \%)$, and then by consultation of pharmacists $(15.1 \%)$ as presented in Table 3. 
Table 3. Mothers' knowledge about the use of ORS.

\begin{tabular}{ccc}
\hline Characteristic & Number & Percentage \\
\hline Do you know the ORS? & 706 & \\
Yes & 434 & 31.9 \\
No & & \\
Role of ORS solution in & & \\
diarrhea & 610 & 53.5 \\
Prevents child from getting dehydrated & 183 & 16.1 \\
Either increases or decreases diarrhea & 77 & 6.8 \\
No role in diarrhea treatment & & 50.3 \\
Sources information of use ORS & 573 & 15.1 \\
Medical prescription & 172 & 15.7 \\
Consultation of pharmacists & 179 & 9.8 \\
Family & 112 & 2.7 \\
Internet & 31 & \\
TV &
\end{tabular}

\subsection{Mothers' Attitude about Childhood Diarrhea Mortality and Treatment}

In this study, around $33.5 \%$ of mothers thought diarrhea can attack bottle-feed children. The majority of mothers $(65.9 \%)$ reported that teething is the main cause of diarrhea. The disagreement that "liquid food aggravates diarrhea" were reported by $22.5 \%$ of the mothers. About $41 \%$ mothers thought that diarrhea is a problem in the Saudi community, and $60.9 \%$ of mothers stated that handwashing prevents diarrhea. More details on mothers' attitude on childhood diarrhea are shown in Table 4.

Table 4. Mothers' attitude about childhood diarrhea.

\begin{tabular}{|c|c|c|c|c|c|}
\hline Questionnaires & $\begin{array}{c}\text { Strongly } \\
\text { Agree } \\
n(\%)\end{array}$ & $\begin{array}{l}\text { Agree } \\
n(\%)\end{array}$ & $\begin{array}{l}\text { Neutral } \\
n(\%)\end{array}$ & $\begin{array}{l}\text { Disagree } \\
n(\%)\end{array}$ & $\begin{array}{c}\text { Strongly } \\
\text { Disagree } \\
n(\%)\end{array}$ \\
\hline $\begin{array}{c}\text { Diarrhea attacks mostly } \\
\text { bottle-feed children }\end{array}$ & $\begin{array}{c}146 \\
(12.8)\end{array}$ & $\begin{array}{c}236 \\
(20.7)\end{array}$ & $\begin{array}{c}522 \\
(45.8)\end{array}$ & $\begin{array}{c}180 \\
(15.8)\end{array}$ & $\begin{array}{c}56 \\
(4.9)\end{array}$ \\
\hline $\begin{array}{c}\text { Diarrhea is a disease of the } \\
\text { poor children }\end{array}$ & $\begin{array}{l}36 \\
(3.2)\end{array}$ & $\begin{array}{c}49 \\
(4.3)\end{array}$ & $\begin{array}{c}223 \\
(19.6)\end{array}$ & $\begin{array}{c}431 \\
(37.8)\end{array}$ & $\begin{array}{c}401 \\
(35.2)\end{array}$ \\
\hline $\begin{array}{l}\text { Diarrhea is a problem in } \\
\text { the community }\end{array}$ & $\begin{array}{c}124 \\
(10.9)\end{array}$ & $\begin{array}{c}347 \\
(30.4)\end{array}$ & $\begin{array}{c}411 \\
(36.1)\end{array}$ & $\begin{array}{c}190 \\
(16.7)\end{array}$ & $\begin{array}{c}68 \\
(6.0)\end{array}$ \\
\hline Teething causes diarrhea & $\begin{array}{c}282 \\
(24.7)\end{array}$ & $\begin{array}{c}470 \\
(41.2)\end{array}$ & $\begin{array}{c}239 \\
(21.0)\end{array}$ & $\begin{array}{l}105 \\
(9.2)\end{array}$ & $\begin{array}{c}44 \\
(3.9)\end{array}$ \\
\hline Diarrhea is a curable disease & $\begin{array}{c}559 \\
(49.0)\end{array}$ & $\begin{array}{c}449 \\
(39.4)\end{array}$ & $\begin{array}{c}81 \\
(7.1)\end{array}$ & $\begin{array}{c}30 \\
(2.6)\end{array}$ & $\begin{array}{c}21 \\
(1.8)\end{array}$ \\
\hline $\begin{array}{l}\text { Liquid food } \\
\text { aggravates diarrhea }\end{array}$ & $\begin{array}{c}111 \\
(9.7)\end{array}$ & $\begin{array}{c}243 \\
(21.3)\end{array}$ & $\begin{array}{c}529 \\
(46.4)\end{array}$ & $\begin{array}{c}209 \\
(18.3)\end{array}$ & $\begin{array}{c}48 \\
(4.2)\end{array}$ \\
\hline Oral rehydration salts & 141 & 368 & $\begin{array}{c}485 \\
(425)\end{array}$ & 122 & 24 \\
\hline $\begin{array}{c}\text { Human feces are a source } \\
\text { of diarrhea }\end{array}$ & $\begin{array}{l}120 \\
(10.5)\end{array}$ & 196 & $\begin{array}{c}648 \\
(568)\end{array}$ & 133 & 43 \\
\hline $\begin{array}{l}\text { Handwashing } \\
\text { prevents diarrhea }\end{array}$ & $\begin{array}{c}248 \\
(21.8)\end{array}$ & $\begin{array}{c}446 \\
(39.1)\end{array}$ & $\begin{array}{c}264 \\
(23.2)\end{array}$ & $\begin{array}{c}122 \\
(10.7)\end{array}$ & $\begin{array}{l}60 \\
(5.3)\end{array}$ \\
\hline
\end{tabular}

\section{Discussion}

This study assessed the mothers' knowledge on the critical signs of diarrhea. About $49 \%$ of the mothers stated that the passage of three or more loose stools with blood during the day is an obvious critical sign of diarrhea that require hospital or physician visit, and almost $23 \%$ reported no knowledge of any critical sign of diarrhea. These results showed low knowledge among Saudi mothers about the critical signs of diarrhea, but their knowledge of the critical signs of diarrhea was higher compared to other mothers in different communities. A study carried out in Ethiopia found that $39.5 \%$ of mothers stated 
that passage of three or more loose stools with blood during the day is the mark of severe diarrhea [17]. A similar study was done in the rural setting of Kenya determined that majority of mothers $(76.4 \%)$ did not identify the critical signs of childhood diarrhea [18]. A study from Nepal reported that $20.8 \%$ of mothers identified red-colored diarrhea as "the most dangerous diarrhea [2]. The critical signs of dehydration have the similar importance to bloody diarrhea, and the participating mothers in our study were unable to identify the most common signs of dehydration. Only $32.1 \%, 11.6 \%$, and $24.3 \%$ were able to recognize thirst/dry mouth, tearless eyes, and loss of strictness of skin, respectively, as the critical signs of dehydration secondary to diarrhea. The poor knowledge and unrecognized signs of dehydration among mothers are noticed globally [2,19-21]. Adequate knowledge about the critical signs of childhood diarrhea is essential as the early referral of a child with severe diarrhea is fundamental for appropriate treatment [17].

Poor sanitation of food and water may lead to diarrhea, with approximately 3000 deaths and 135,000 hospitalizations annually secondary to the food-borne transmission of diarrhea causative pathogens in the United States [22]. In regards to the causes and transmission of diarrhea, nearly $50 \%$ of participating mothers believed that eating polluted food is the most common cause of childhood diarrhea, and only $31 \%$ of mothers identified drinking unclean water as the reason for childhood diarrhea. In consistent with our findings, many studies reported a low level of mothers towards causes and transmission of diarrhea. $[2,17,23]$. A study from Nigeria reported that the most common causes for childhood diarrhea were contaminated food $(24.1 \%)$ and unclean water $(11.3 \%)$ [8]. Another study from Iran showed that only $24.66 \%$ of mothers knew that unclean water can cause diarrhea [24]. A study was carried out in Malawi reported that $55 \%$ of mothers stated that unhealthy water is the main cause of diarrhea [25]. The change in knowledge of childhood diarrhea could be due to variance in mothers' education levels.

The misconception between teething and diarrhea seems disseminated widely. The results of the present study showed that $66 \%$ of mothers stated teething is a reason for their child's diarrhea. These results come agreed with other studies from different countries $[8,24]$. In addition to the wrong belief of association between diarrhea and teething, mothers tend to consider diarrhea secondary to teething as "non-serious diarrhea", and they may deal with it loosely even if it's accompanied by critical signs like dehydration [26]. The efforts should be applied to educate the mothers about the critical signs of diarrhea in children, and to disassociate the belief link between diarrhea and teething.

The mothers' sufficient knowledge on reasons, prevention, and management of diarrhea utilizing proper therapies is the key for home management of childhood diarrhea [14,27]. According to the Integrated Management of Childhood Illness (IMCI) guidelines, the use of ORS is the principle therapy of diarrhea [28]. However, the use of ORS seemed not highly encouraging among mothers. Although $62 \%$ of our participating mothers knew about the ORS, only $23.5 \%$ of them used it for their children. Similar findings were reported. A study from Nigeria reported that most mothers (63\%) were aware of ORS, but $27 \%$ of them used it for their children. In another study did in Pakistan mentioned that $58 \%$ of mothers used ORS to treat their childhood diarrhea disease [12]. Moreover, in our study, it was found the main resources of mothers regarding ORS usage were medical prescriptions $(50.3 \%)$, family/relatives/friends (15.7\%), and pharmacists $(15.1 \%)$. In a similar study, the two main resources of ORS information were families/friends (76\%) and pediatricians (58\%) [29]. Despite 53.3\% of our participants reporting that "ORS prevents a child from getting dehydrated", few mothers are using ORS (23.5\%). The reason for a few mothers used ORS could be due to their level of education and awareness of the mothers on diarrhea management, due to inadequate public information on this issue.

This study was conducted online to diminish geographical dependence, and because of the high rate of literacy and social media usage among Saudis [30,31], as well as this study's aim to assess the knowledge, attitude, and practice of mothers towards childhood diarrhea from a community perspective. The study was performed with significance 
that mothers' knowledge of childhood diarrhea prevention and management would decrease the unnecessary hospital or clinic visits; however, most of the participating mothers $(68.9 \%)$ seek treatment from a medical doctor for their children with diarrhea. This practice of mother was observed in a previous study [17]. In contrast, our subjects showed good preventive measures. The majority of mothers $(70.9 \%)$ believed that handwashing, which is one essential measure to decrease the prevalence of diarrhea [32], prevents childhood diarrhea.

\section{Conclusions}

Approximately $40.3 \%$ of participating mothers believed that childhood diarrhea is a major problem in the Saudi community. These beliefs are supported by reports mentioned the prevalence of diarrhea is high in some areas of Saudi Arabia [1]. However, insufficient knowledge of childhood diarrhea and its management were observed. Adequate knowledge about the critical signs, causes, transmission, prevention, and management of childhood diarrhea should be applied in simple language to communicate the healthrelated information clearly. Moreover, there is a lack of knowledge on the role of ORS and its use. The general understanding of ORS is not adequate and needs reliable efforts to highlight its importance in resolving dehydration of childhood diarrhea.

Author Contributions: Conceptualization, S.A., W.S., A.A. (Abdulrahman Alwhaibi) and S.D.B. and M.N.A.A., A.A. (Abdulaziz Alhossan) and Z.A.; Statistical analysis, W.S., S.D.B., A.A. (Abdulaziz Alhossan), A.A. (Abdulrahman Alwhaibi); Investigation, M.N.A.A., Z.A., W.S. and A.A. (Abdulaziz Alhossan); Methodology, W.S., and S.D.B., A.A. (Abdulaziz Alhossan); Writingoriginal draft W.S. and S.D.B.; Writing-review and editing, W.S., S.D.B., S.A., and Z.A., A.A. (Abdulrahman Alwhaibi), A.A. (Abdulaziz Alhossan). All authors have read and agreed to the published version of the manuscript.

Funding: This study was funded by Deanship of Scientific Research at King Saud University, Riyadh, Saudi Arabia through research group no. RG-1440-098.

Institutional Review Board Statement: The study was exempted from the Institutional Review Board. Although study was conducted according to the guidelines of the Declaration of Helsinki.

Informed Consent Statement: Informed consent was obtained from all subjects involved in the study.

Data Availability Statement: Data will be available upon request from the corresponding author of the study.

Acknowledgments: The authors extend their appreciation to the Deanship of Scientific Research at King Saud University for funding this work through research group no. RG-1440-098.

Conflicts of Interest: The authors declare that they have no competing interests.

\section{References}

1. Bani, I.; Saeed, A.; Othman, A. Diarrhoea and child feeding practices in Saudi Arabia. Public Health Nutr. 2002,5 , 727-731. [CrossRef] [PubMed]

2. Mukhtar, A.; Mohamed Izham, M.I.; Pathiyil, R.S. A survey of mothers' knowledge about childhood diarrhoea and its management among a marginalised community of Morang, Nepal. Australas. Med. J. 2011, 4, 474-479. [PubMed]

3. AlAyed, M.Z.; Asaad, A.M.; Mahdi, A.A.; Qureshi, M.A. Aetiology of acute gastroenteritis in children in Najran region, Saudi Arabia. J. Health Spec. 2013, 1, 84-89. [CrossRef]

4. Centers for Disease Control and Prevention. Diarrhea: Common Illness, Global Killer. Available online: https://www.cdc.gov / healthywater/global/diarrhea-burden.html (accessed on 15 March 2019).

5. Platts-Mills, J.A.; Babji, S.; Bodhidatta, L. Pathogen-specific burdens of community diarrhoea in developing countries: A multisite birth cohort study (MAL-ED). Lancet Glob. Health 2015, 3, e564-e575. [CrossRef]

6. Milaat, W.A.; Elassouli, S.M. Epidemiology of Diarrhea in Two Major Cities in Saudi Arabia. Paediatr. Indones. 1995, 35, 124-131. [CrossRef]

7. Tayeb, H.T.; Balkhy, H.H.; Aljuhani, S.M.; Elbanyan, E.; Alalola, S.; Alshaalan, M. Increased prevalence of rotavirus among children associated gastroenteritis in Riyadh Saudi Arabia. Virol. J. 2011, 8, 548. [CrossRef] [PubMed] 
8. Adimora, G.N.; Ikefuna, A.N.; Ilechukwu, G. Home management of childhood diarrhoea: Need to intensify campaign. Niger. J. Clin. Pract. 2011, 14, 237-241. [CrossRef]

9. Workie, H.M.; Sharifabdilahi, A.S.; Addis, E.M. Mothers' knowledge, attitude and practice towards the prevention and homebased management of diarrheal disease among under-five children in Diredawa, Eastern Ethiopia, 2016: A cross-sectional study. BMC Pediatrics 2018, 18, 358. [CrossRef]

10. Al-Ghamdi, M.A.; Bentham, G.; Hunter, P.R. Environmental risk factors for diarrhoea among male schoolchildren in Jeddah City, Saudi Arabia. J. Water Health 2009, 7, 380-391. [CrossRef]

11. Desta, B.K.; Assimamaw, N.T.; Ashenafi, T.D. Knowledge, Practice, and Associated Factors of Home-Based Management of Diarrhea among Caregivers of Children Attending Under-Five Clinic in Fagita Lekoma District, Awi Zone, Amhara Regional State, Northwest Ethiopia, 2016. Nurs. Res. Pract. 2017, 2017, 8084548. [CrossRef]

12. Masiha, S.A.; Khalid, A.; Malik, B.; Shah, S.M. Oral rehydration therapy-knowledge, attitude and practice (KAP) survey of Pakistani mothers. J. Rawalpindi Med. Coll. Stud. Suppl. 2015, 19, 51-54.

13. Mwambete, K.D.; Joseph, R. Knowledge and perception of mothers and caregivers on childhood diarrhoea and its management in Temeke municipality, Tanzania. Tanzan. J. Health Res. 2010, 12, 47-54. [CrossRef]

14. Zwisler, G.; Simpson, E.; Moodley, M. Treatment of diarrhea in young children: Results from surveys on the perception and use of oral rehydration solutions, antibiotics, and other therapies in India and Kenya. J. Glob. Health 2013, 3, 010403. [CrossRef]

15. Bella, H.; Ai-Freihi, H.; El-Mousan, M.; Danso, K.T.; Sohaibani, M.; Khazindar, M.S. Knowledge, Attitudes and Practices related to Diarrhoea in Eastern Province, Saudi Arabia. J. Fam. Community Med. 1994, 1, 40-44.

16. Shati, A.A.; Khalil, S.N.; Asiri, K.A.; Alshehri, A.A.; Deajim, Y.A.; Al-Amer, M.S.; Alshehri, H.J.; Alshehri, A.A.; Alqahtani, F.S. Occurrence of Diarrhea and Feeding Practices among Children below Two Years of Age in Southwestern Saudi Arabia. Int. J. Environ. Res. Public Health 2020, 17, 722. [CrossRef]

17. Nigatu, M.; Tadesse, A. Knowledge, perception, and management skills of mothers with under-five children about diarrhoeal disease in indigenous and resettlement communities in Assosa district, western Ethiopia. J. Health Popul. Nutr. 2015, 33, 20-30.

18. Othero, D.M.; Orago, A.S.; Groenewegen, T.; Kaseje, D.O.; Otengah, P.A. Home management of diarrhea among under-fives in a rural community in Kenya: Household perceptions and practices. East Afr. J. Public Health 2008, 5, 142-146.

19. MacDonald, S.E.; Moralejo, D.G.; Mathews, M.K. Maternal understanding of diarrhoea-related dehydration and its influence on ORS use in Indonesia. Asia Pac. J. Public Health 2007, 19, 34-39. [CrossRef]

20. Gupta, N.; Jain, S.K.; Ratnesh Chawla, U.; Hossain, S.; Venkatesh, S. An evaluation of diarrheal diseases and acute respiratory infections control programmes in a Delhi slum. Indian J. Pediatr. 2007, 74, 471-476. [CrossRef]

21. Delgado, M.F.; Sierra, C.H.; Calvache, J.A.; Rios, A.M.; Mosquera, C.; Salas, I.; Agredo, F.; Meneses, R. Maternal knowledge about children's danger signs in acute diarrhoea in an IMCI's frame. Colomb. Med. 2006, 37, 293-298.

22. Walker, P. Chapter 16: Diarrhea. In Handbook of Nonprescription Drugs: An Interactive Approach to Self-Care, 19th ed.; Krinsky, D., Ed.; American Pharmacists Association: Washington DC, USA, 2017; pp. 268-269.

23. Ashraf, A.; Bhat, M.A. Childhood diarrhoea: Assessment of knowledge, attitude and practices among mothers attending the tertiary care hospital-an observational analytical study. Int. J. Community Med. Public Health 2017, 4, 1219-1222. [CrossRef]

24. Khalili, M.; Mirshahi, M.; Zarghami, A.; Rajabnia, M.; Farahmand, F. Maternal knowledge and practice regarding childhood diarrhea and diet in Zahedan, Iran. Health Scope 2013, 2, 19-24. [CrossRef]

25. Masangwi, S.J.; Grimason, A.M.; Morse, T.D.; Kazembe, L.; Ferguson, N.; Jabu, G.C. Pattern of maternal knowledge and its implications for diarrhoea control in Southern Malawi: Multilevel thresholds of change analysis. Int. J. Environ. Res. Public Health 2012, 9, 955-969. [CrossRef]

26. Den Besten, P. Is teething associated with diarrhea? West. J. Med. 2000, 173, 137. [CrossRef]

27. Olson, C.K.; Blum, L.S.; Patel, K.N.; Oria, P.A.; Feikin, D.R.; Laserson, K.F.; Wamae, A.W.; Bartlett, A.V.; Breiman, R.F.; Ram, P.K. Community case management of childhood diarrhea in a setting with declining use of oral rehydration therapy: Findings from cross-sectional studies among primary household caregivers, Kenya, 2007. Am. J. Trop. Med. Hyg. 2011, 85, 1134-1140. [CrossRef]

28. WHO. Handbook IMCI Integrated Management of Childhood Illness; WHO: Geneva, Switzerland, 2005.

29. Kudlova, E. Home management of acute diarrhoea in Czech children. J. Pediatr. Gastroenterol. Nutr. 2010, 50, 510-515. [CrossRef]

30. World Health Orginzation. Country Cooperation Strategy at Glance: Saudi Arabia. Available online: http://apps.who.int/iris/ bitstream/10665/136842/1/ccsbrief_sau_en.pdf (accessed on 14 May 2019).

31. Global Media Insight. Saudi Arabia Social Media Statistics 2018. Available online: https://www.globalmediainsight.com/blog/ saudi-arabia-social-media-statistics (accessed on 14 May 2019).

32. Ejemot-Nwadiaro, R.I.; Ehiri, J.E.; Arikpo, D.; Meremikwu, M.M.; Critchley, J.A. Hand washing promotion for preventing diarrhoea. Cochrane Database Syst. Rev. 2015, 9, 1-95. [CrossRef] 